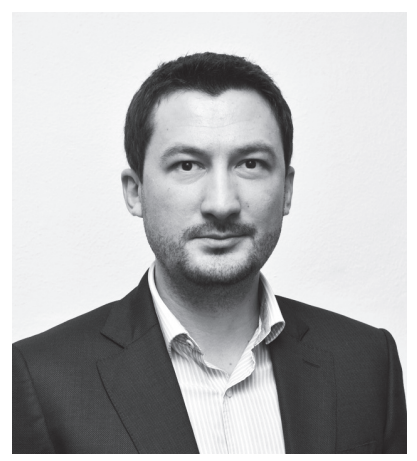

Igoris Koroliovas - filologijos mokslų daktaras, docentas, Kijevo Taraso Ševčenkos nacionalinio universiteto (Ukraina) Bendrosios kalbotyros ir klasikinès filologijos habilitacinis doktorantas.

Moksliniai interesai: bendroji kalbotyra, komunikatyvinė ligvistika, kultūrinè kalbotyra.

El.paštas: korolyovigor@gmail.com.

Igor Korolyov - PhD, Associate Professor, Post-Doctoral Researcher of General Linguistics and Classical Philology Department, Taras Shevchenko National University of Kyiv (Ukraine)

Research interests: general linguistics, linguistic communication, cultural linguistics.

E-mail: korolyovigor@gmail.com.

\title{
Игорь Королёв
}

Киевский национальный университет имени Тараса Шевченко

\section{СТЕРЕОТИПНЫЕ ПРЕДСТАВЛЕНИЯ}

УКРАИНЦЕВ, РУССКИХ И ЛИТОВЦЕВ О КООПЕРАТИВНОМ КОММУНИКАТИВНОМ ПОВЕДЕНИИ (по результатам

эмпирического исследования)

\begin{abstract}
Anotacija
Straipsnyje nagrinejjami ukrainiečių, rusų ir lietuvių lingvokultūrų atstovų stereotipiniai kooperatyvinio komunikacinio elgesio vaizdiniai kognityviniame komunikaciniame kooperavimosi kontekste. Apibūdinami nacionalinio komunikacinio elgesio stereotipo kūrimo procesai ir mechanizmai, pažymimi sąvokos „kooperavimasis“, taip pat kooperatyvinès kalbinès asmenybės individualūs ir kolektyviniai stereotipiniai vaizdiniai ukrainiečių, rusų ir lietuvių komunikacijos kultūrose remiantis empiriniais tyrimais (socialiniais ir psicholingvistiniais eksperimentais). Nustatomi universalūs ir specifiniai ukrainiečių, rusų ir lietuvių komunikacinio kooperavimosi lygio auto- ir heterostereotipu parametrai.

PAGRINDINIAI ŽODŽIAI: nacionaliniai komunikacijos ypatumai, stereotipų tipologija, auto- ir heterostereotipai, ukrainiečių (rusų, lietuvių) komunikacijos kultūra.
\end{abstract}

\footnotetext{
Abstract

The article examines the stereotypes of the Ukrainian, Russian and Lithuanian linguocultures of cooperative communicative behaviour in the context of cognitive and communicative categories of cooperativity. The process and mechanisms of stereotyping the national communicative behaviour have been characterized, the individual and collective
} 


\section{Игорь Королёв \\ Стереотипные представления украинцев, русских и литовцев о кооперативном коммуникативном поведении (по результатам эмпирического исследования)}

stereotypical impressions about the concept of "cooperativity", as well as the cooperative linguistic individual in Ukrainian, Russian and Lithuanian communicative cultures have been identified on the results of empirical research (due to the socio- and psycholinguistic experiments). The universal and national specific parameters of auto- and hetero-stereotypes of Ukrainian, Russians and Lithuanians on their level of cooperativity in communication have been established.

KEY WORDS: national communicative behaviour, typology of stereotypes, auto- and hetero-stereotype, cooperativity, Ukrainian (Russian, Lithuanian) communicative culture.

DOI: http://dx.doi.org/10.15181/rh.v19i0.1328

Исследование особенностей монокультурного и межкультурного общения, в том числе коммуникативного поведения, длительное время находится в фокусе внимания специальных студий психологов (М. С. Андрианова, Т. В. Ахутиной, Э. Берна, И. И. Васильевой, Т. М. Дридзе, М. Томаселло), социологов (С. В. Бориснёва, Р. Григаса, Н. Я. Данилевского, В. П. Конецкой, Ф. И. Шаркова, И. П. Яковлева), историков, политологов, этнографов, культурологов (М. Н. Грачёва, Л. П. Марьиной, А. В. Павловской, Н. Ф. Пономарёва, А. В. Соколова), лингвистов (М. М. Бахтина, Ф. С. Бацевича, Т. Г. Винокур, В. М. Глушака, О. С. Иссерс, В. И. Карасика, В. Б. Кашкина, Л. П. Крысина, Т. В. Лариной, О. А. Леонтович, А. Б. Лихачёвой, Ю. Е. Прохорова, К. Ф. Седова, И. И. Серяковой, М. С. Скаба, Л. В. Солощук, И. А. Стернина, С. Г. Тер-Минасовой, Н. И. Формановской и др.), которые дают основания предположить, что в национальном коммуникативном поведении проявляются психологические, лингвистические, лингвокультурные закономерности и особенности общения коммуникантов, принадлежащих к тому или иному этносу.

Основой мировоззрения и миропонимания каждого народа является собственная система предметных значений, социальных стереотипов, когнитивных схем. Именно такая системность сознания, или образа мира, влияет на поведение представителей той или иной лингвокультуры и определяется ею (Уфимцева 1996, 160). О возможности лингвистического описания различных составляющих и характеристик национального коммуникативного поведения свидетельствуют труды последних лет как украинских (Ф. С. Бацевича, Я. К. Радевич-Винницкого, С. К. Богдан, Л. Гнатюк, Т. А. Космеды, 
О. М. Ильченко, И. И. Серяковой, Л. В. Солощук, М. С. Скаба, М. А. Стахив, М. А. Шутовой и др.), российских (И. А. Стернина, Т. В. Лариной, А. В. Павловской, Ю. Е. Прохорова, А. В. Сергеевой, С. Г. Тер-Минасовой, Н. И. Формановской, О. В. Харченко, Р. В. Бухаевой, А. О. Стеблецовой и др.), так и литовских (А. Б. Лихачёвой, Й. Паужи, Р. Чичинскайте, Э. Р. Лассан, В. Макаровой, А. Кучинскайте, Г. Чепайтьене и др.) исследователей, однако интерес к этому уникальному феномену не исчерпывается представленной традицией в его изучении.

Актуальность данной статьи связана с необходимостью системного и комплексного описания кооперативного коммуникативного поведения восточнославянских (украинцев и русских) и балтийских (литовцев) этносов, в частности их стереотипных представлений о кооперативности в общении.

Объектом исследования являются стереотипные представления украинцев, русских и литовцев о кооперативном коммуникативном поведении сквозь призму понятия когнитивно-коммуникативной категории кооперативности, а предметом - выявление специфики индивидуальных и коллективных авто- и гетеростереотипов о понятии кооперативность в украинской, русской и литовской лингвокультурах.

Целью статьи является определение индивидуальных и коллективных авто- и гетеростереотипных представлений о кооперативности в украинской, русской и литовской коммуникативных культурах. Задачи: - охарактеризовать процесс и механизмы стереотипизации национального коммуникативного поведения; выявить индивидуальные и коллективные стереотипные представления о кооперативности в украинской, русской и литовской коммуникативных культурах по результатам эмпирического исследования (социо- и психолингвистического экспериментов); - систематизировать индивидуальные и коллективные стереотипные представления о кооперативной языковой личности в украинской, русской и литовской лингвокультурах; - параметризировать уровни авто- и гетеростереотипов украинцев, русских и литовцев об их кооперативности в общении.

С опорой на теоретико-методологические основы изучения коммуникативного поведения, введенные в научный оборот И. А. Стерниным (Коммуникативное поведение 2007), в наших предыдущих 
работах была предпринята попытка незначительной модификации его параметрической модели описания и предложена собственная параметрическая модель измерения национального кооперативного коммуникативного поведения, основными составляющими которой считаем традиции культуры, нормы, модусы, принципы, аспекты, факторы, параметры, сферы и типы (см. подробнее Корольов 2016). По мнению И. Стернина, до сих пор близкородственные коммуникативные культуры, к которым относятся украинская и русская, почти не подвергались системно-контрастивной параметризации, что обусловлено наличием определенных трудностей, связанных с высокой степенью их близости (Стернин 2015). Предполагаем, что под близостью здесь ученый понимает этнокультурную составляющую, то есть общее прошлое, в котором вместе формировались установки для приемлемого общения и т.п. Именно поэтому в исследованиях соответствующей проблематики изредка постулируются конкретные эндемичные или лакунарные коммуникативные факты и явления, поскольку именно этот вопрос приобрел статус стереотипов в научной среде, а выявление коммуникативных различий в подобных этнокультурах, характеризующихся не наличием или отсутствием отдельных признаков (действий) в речевом поведении, а степенью их проявления в общении и измерением частотности, имеют, прежде всего, важное культурологическое и лингводидактическое значение.

Относительно анализа коммуникативного поведения восточнославянских этносов М. Скаб справедливо отмечает, что “наиболее интересными и самыми тонкими являются сопоставительные студии коммуникационного поведения родственных и близкородственных народов, поскольку, изучив общие закономерности коммуникационного поведения представителей определенного этноса и сопоставив их с такими же чертами представителей другого этноса, можем сделать предварительные выводы о том, что может стать причиной коммуникационных девиаций и конфликтов, а следовательно, основанием для разработки конкретных рекомендаций по совершенствованию коммуникационной компетенции говорящих, формированию у них устойчивых навыков подобного поведения, прежде всего, в стандартных ситуациях общения” (Скаб 2015, 5-6). 
Подобная постановка проблемы вызывает необходимость более глубокого осмысления процесса и механизмов стереотипизации национального коммуникативного поведения и его отражения в сознании говорящих. В типичных коммуникативных монокультурных и межкультурных ситуациях любой интерактант обращается к сложившейся и закрепленной в собственном сознании системе стереотипов с целью организации восприятия и декодирования информации, предоставления ей определенной оценки и интерпретации. Сделав конкретные выводы, коммуникант соответственно строит на их основании собственное речевое поведение, поскольку система его стереотипов может остаться как неизменной, так и поддаться корректировке в зависимости от того, насколько партнер в общении подтверждает или опровергает своим поведением устоявшиеся стереотипы.

Для реализации поставленной задачи мы должны определиться с типами стереотипов, находящихся в фокусе нашего внимания согласно специфике проведения эмпирического исследования. Так, по параметру субъекта стереотипизации мы будем анализировать индивидуальные (социальные - этот термин также связан с объектом стереотипизации, где, соответственно, имеет другое значение, связанное с определенными группами) стереотипы, пытаясь сделать предположения уже на уровне коллективных (культурных) стереотипов, которыми можно считать стереотипы с достаточно высоким уровнем согласованности и распространенности (см. подробнее Нельсон 2003). Стоит отметить, что зачисление каких-либо стереотипов к коллективным не имплицирует и не предусматривает “их полного тождества у отдельных индивидов или одинакового осознания всеми представителями группы” (Стефаненко 1999, 244). Как правило, коллективные стереотипы “проявляют себя через стереотипы индивидуальные (социально-психологические), получая при этом дополнительную индивидуально-личностную окраску” (Семендяева 1986, 156).

По параметру объекта стереотипизации, будем рассматривать социальные антропостереотипы, касающиеся как отдельного человека, так и определенной объединенной по разным принципам (этническим, культурным, профессиональным и т.д.) социальной группы (Сорокина 2013, 124). Согласно специфике организации и построения анкеты, предложенной респондентам, были учтены стереотипы 
персоналий, касающиеся отдельного интерактанта (индивидуальные), а также коллективные стереотипы, характеризующие определенную социальную (этническую, национальную) группу и коммуникантов как ее членов. Кроме того, проблематика опроса предусматривала выяснение понимания информантами такой когнитивно-коммуникативной категории, как кооперативность. Именно поэтому по объекту стереотипизации в ракурсе нашего внимания будут находиться предметные (понятийные) стереотипы. Безусловно, предлагаемый подход к объекту стереотипизации в нашем исследовании современен и актуален, поскольку базируется на широком понимании возможных объектов стереотипизации, согласно которому ими могут выступать любые предметы, явления, события действительности и т.д. (Донец 2001, 183-188).

Согласно оппозиции “свой-чужой”, обусловленной принадлежностью субъекта стереотипизации к объекту (определенной социальной, этнической, национальной группы), попробуем проанализировать как автостереотипы (образ-представление субъекта стереотипизации о самом себе, когда субъект фактически совпадает с объектом), так и гетеростереотипы (образ-представление субъекта стереотипизации о Другом). Значительный вклад в развитие этой стратификации стереотипов внесла психолог Г. У. Солдатова, по мнению которой “авто- и гетеростереотипы - это не автономные единицы, а структурно взаимосвязанные компоненты единого целостного образования личностного и группового самосознания” (Солдатова 1998, 70). В работе употребляем термины “авто-, гетеростереотип”, хотя в науке существуют и другие терминообозначения этого явления, в частности “эндо-, экзостереотип” (Леонтович 2005), “eigen- (selbst-) und fremdstereotyp / auto- und heterostereotyp” (Löschmann 2001), "in-group and out-group stereotype" (Castano 2002).

Согласно параметру содержания аффективного компонента, стереотипы делятся на позитивные и негативные (Сорокина 2013, 130), которые иногда отождествляются с отрицающими (агрессивное содержание) и утверждающими (нейтральный / безобидный смысл) (Quasthoff 1989, 46). Как правило, когнитивный компонент подобных стереотипов может совпадать, а аффективный - отличаться, что зависит от субъекта и объекта стереотипизации, в частности от их 
взаимоотношений. Учитывая специфику проведенного опроса, предусматривавшего выявление понимания реципиентами понятия когнитивно-коммуникативной категории кооперативности, не можем не обратиться к интересной и важной типологии стереотипов, предложенной социологом Ю. С. Метёлкиной, которая классифицировала их по соотношению компонентов структуры (рационального / когнитивного, эмоционального / аффективного, моторного / поведенческого) на предубеждения (предрассудки), эвристики, традиции и нормы. В каждом из четырех типов стереотипов, по мнению исследовательницы, доминирует отдельный компонент структуры, имея определенный вектор влияния на другой. Предубеждением (предрассудком) она считает высказывание “люди преклонного возраста недееспособные” с доминантным отрицательным аффективным компонентом (которому может противоречить рациональный), влияющий на поведенческий; эвристикой - “воспитание детей - женское дело” с преобладанием рационального компонента, который дополняется эмоциональным, определяющими в совокупности поведенческий; традицией - “официальная регистрация семейных отношений”, где главным является моторный компонент, определяющий другие по принципу «все люди так делают, поэтому это правильно»; нормой “никто не гуляет по улицам без одежды”, в которой основным является эмоциональная составляющая структуры, формирующий два других по формуле “это неправильно (некрасиво, нехорошо, неэтично), а потому это глупо, и никто так себя не ведет” (Метелкина 2002 , 51-52).

В лингвистической литературе существуют и другие типологии стереотипов. Так, Р. В. Бухаева, в фокусе внимания которой находится стереотипное речевое поведение бурят и русских, выделяет следующие виды стереотипов: языковые стереотипы (стандарт, норма, нормированные речевые обороты); речевые стереотипы (клише, штампы, шаблоны, стандарты); стереотипы поведения (речевой этикет, жесты, мимика); ментальные стереотипы / стереотип сознания (представления о людях, предметы, объекты, явления, ситуации (Бухаева 2015, 69). В соответствии со спецификой предлагаемой типологии стереотипов исследовательница стратифицирует уровни общения на четыре вида: 1) языковой (речевые клише, фразеологизмы, прецедентные 
имена и их коннотации); 2) содержательный (речевой этикет, фоновые знания); 3) паралингвистический (кинетика, проксемика); 4) ментальный (стереотипы-концепты, слова-образы) (Бухаева 2015, 81-82).

По нашему мнению, концептуально оправдано и вполне логично было бы добавить к смысловому уровню общения рассмотрение прагматических пресуппозиций (которые автор, вероятно, считает “фоновыми знаниями”), коммуникативных стратегий и тактик коммуникантов, а также их социальных ролей. Паралингвистический уровень мы предложили бы называть невербальным, поскольку именно этот термин объединяет значительно большее количество составляющих, касающихся не только кинетических и проксемических характеристик процесса общения, но и элементов такесики, мимики, просодики, выражение эмоций через психофизиологические реакции (плач, цвет лица и т.д.). Относительно структуры стереотипов речевого общения согласны с Р. В. Бухаевой, которая рассматривает ее в контексте стереотипов языкового сознания, выделяя стереотипы-концепты и национально-культурные слова-образы, а также стереотипы организации речевого общения (стереотипы коммуникативного поведения) (Бухаева 2015, 104).

Стереотипные представления представителей различных национальных коммуникативных культур влияют как на процессы общения в межкультурной коммуникации, так и в монокультурной, в частности на групповом и индивидуальном уровнях, эксплицитно и имплицитно, могут быть осознанными и неосознаваемыми. С целью выявления стереотипных представлений украинцев, русских и литовцев о кооперативном коммуникативном поведении сквозь призму понятия когнитивно-коммуникативной категории кооперативности, а также закономерностей и специфики ее реализации в коммуникативном поведении, был использован антропометрический метод и проведено эмпирическое исследование в виде социо- и психолингвистического экспериментов. Основу анкеты, распространенной среди информантов, составили вопросы, сформулированные Т. В. Лариной, которая системно и основательно проанализировала категорию вежливости в аспекте сопоставления английских и русских лингвокультурных традиций (см. подробнее Ларина 2009). Опрос был проведен в течение марта-мая 2016 года в электронном виде с использованием 
Google-формы на украинском, русском и литовском языках согласно принадлежности респондентов к соответствующей коммуникативной культуре. Обрабатывались ответы, поступившие от 100 информантов, представляющих отдельную исследуемую лингвокультуру.

Учитывая специфику проблематики эмпирического исследования, необходимо охарактеризовать процедуру проведения экспериментов. Респонденты сначала могли ответить на вопросы, касающиеся социолингвистических параметров, в том числе о поле, возрасте, месте рождения, национальности, родном языке и языке, на котором преимущественно общаются, уровне их образования, профессии (специальности, роде деятельности). В рамках представленной статьи, достигая реализации ее цели и опираясь на поставленные задачи, мы коротко остановимся лишь на отдельных характеристиках этого блока анкеты.

Так, подавляющее большинство информантов во всех трех коммуникативных культурах являются представителями женского пола $85 \%$ в украинской и литовской и $73 \%$ - в русской. Отвечали разные по возрасту респонденты во всех трех лингвокультурах, но среди украинцев самыми активными были от 17 до 30 лет (66,6 \%); среди россиян - от 31 до 50 лет (50 \%); среди литовцев от 40 лет и старше $(58,8$ \%). По месту рождения, национальности, родному языку и языку общения наиболее однородные показатели во всех трех коммуникативных культурах, превышающие 90 \%, что связано с самоидентификацией информанта как гражданина своей страны и представителя, соответственно, украинского, российского и литовского этносов. Необходимо лишь отметить, что 80 \% респондентов из Украины считают родным языком украинский, тогда как общаются преимущественно на нем $66 \%$ (33 \% - на русском, $3 \%$ - на других (на английском, польском языках). Россияне и литовцы преимущественно общаются на русском и литовском языках соответственно (по $100 \%$ ), лишь $3 \%$ представителей русской и $23 \%$ информантов литовской лингвокультур одновременно используют в повседневной коммуникации другие языки.

Согласно типологии социального статуса языковой личности, представленной в работах психологов (Федотова 2016), лингвистов (Карасик 1992), отметим, что целенаправленно распространяли раз- 
работанную анкету среди представителей украинской, русской и литовской лингвокультур со средним и высоким социальным статусом, которые соответственно имеют средний и высокий уровень языковой и коммуникативной компетенции, выделяемый в лингвоперсонологии. Респонденты из трех исследуемых коммуникативных культур имеют высокий уровень образования, в том числе с ученой степенью и полным высшим образованием - 43,7 \% украинцев, 86,5 \% русских и 73,6 \% литовцев. Неполное высшее образование среди информантов имеют 41,5 \% украинцев, 10 \% русских и 18 \% литовцев, продолжающих обучение в высших учебных заведениях.

Относительно профессиональной принадлежности информантов можем отметить, что во всех трех лингвокультурах наибольшую по численности группу составляли коммуниканты, которые по специальности являются филологами. Кроме того, среди украинских респондентов участвовали в эмпирическом исследовании педагоги и ученые (учителя и преподаватели дисциплин нефилологического цикла (начальное обучение, философия, богословие, история, геология, геофизика, геоинформатика, юриспруденция, управление учебным заведением, физиология и т.д.), аспиранты и докторанты), программисты, журналисты, экономисты, юристы, методисты и радиомеханик. Среди русских информантов обрабатывали анкету в основном сотрудники (преподаватели, аспиранты, докторанты, методисты) и студенты высших учебных заведений, но поступали единичные ответы и от специалистов в области экономики, логистики и снабжения, обслуживания вентиляционного оборудования, переводчиков, журналистов и редакторов. Среди литовских респондентов наибольшая численность работает или учится в высших учебных заведениях и имеет отношение к гуманитарным наукам в целом (психологии, педагогике, этнологии) и филологии в частности. Однако в эмпирическом исследовании также приняли участие специалисты в области управления, менеджеры и администраторы, журналисты из Литвы.

Следующий блок анкеты посвящен непосредственно когнитивнокоммуникативной категории кооперативности, в частности стереотипным представлениям интерактантов, представляющих украинскую, русскую и литовскую лингвокультуры, о понимании и интепретации этого понятия. Перед обработкой результатов обратимся к толковым 
словарям украинского, русского и литовского языков и обнаружим, что статьи с реестровыми словами укр. кооперативність, рус. коопеpamuвность, лит. kooperatyvumas в академических словарях нет. В то же время в их составе имеются дефиниции лексемы укр. 'кооперація', рус. 'кооперация’, лит. 'kоорега̃cija'. Можем констатировать общее значение для трёх языков, зафиксированное в академических словарях: укр.: особлива форма організації праці, при якій багато людей разом беруть участь у тому самому процесі або в різних, але зв'язаних між собою процесах праці; співробітництво (Словник української мови 1973, Т. 4, 277); рус.: форма организации труда, при которой много лиц планомерно, совместно друг с другом, участвуют в одном и том же или в различньх, связанньх между собою процессах труда; вообще форма связи между промьшиленньми организациями, цельми сферами производственной деятельности, кооперация труда (Ожегов, Шведова 2006); лит.: darbo organizavimo forma, kai daugelis žmoniu ar ju kolektyvu dalyvauja tame pačiame arba artimuose darbo procesuose: darbo kooperãcija (Dabartinès lietuvių kalbos žodynas 2006 (2011)). Таким образом, в толковых словарях зафиксирована основная архисема лексемы кооперация - 'процессы сотрудничества людей'.

Поскольку проблематика нашего исследования носит психолингвистический характер, то считаем необходимым обратиться к определению понятия кооперация в психологии. Итак, в соответствии с Большой психологической энциклопедией, кооперация (от лат. cooperatio - сотрудничество) является “одной из основных форм организации межличностного взаимодействия, характеризующаяся объединением усилий участников для достижения общей цели при одновременном разделении между ними функций, ролей и обязанностей” (Большая психологическая энциклопедия 2007). Взаимодействие и сотрудничество людей во все времена предопределяли поиск обоюдной пользы, объединение усилий для достижения лучших и самых ожидаемых результатов.

В блоке анкеты со свободным ассоциативным характером информанты могли охарактеризовать понятие кооперативность и описать черты кооперативной языковой личности в процессе общения, что обусловило необходимость объединения и типологизации определенных свойств и признаков, отмеченных реципиентами. Мы сознательно 


\section{Игорь Королёв \\ Стереотипные представления украинцев, русских и литовцев о кооперативном коммуникативном поведении (по результатам эмпирического исследования)}

предлагаем говорить о так называемых стереотипных представлениях о кооперативном коммуникативном поведении на фоне понимания когнитивно-коммуникативной категории кооперативности, опираясь на то, что это понятие не является устойчивым и общепринятым в лингвокоммуникативистике, не входит в узус большинства реципиентов, что предоставит нам возможность сделать определенные предварительные выводы только об упрощенных, наивных представлениях информантов, касающихся изучаемого явления. При классификации ответов респондентов трех исследуемых коммуникативных культур нам удалось выделить шесть типов стереотипных представлений о “кооперативности” (заметим, что выделенные типы не существуют изолированно в так называемом “чистом виде”, а в большинстве случаев пересекаются, взаимодополняют друг друга, что, соответственно, доказывает вероятность сконструированной нами параметрической модели измерения национального кооперативного коммуникативного поведения, которая, в свою очередь, предполагает взаимосвязь каждого из своих элементов и составляющих:

1) процесс общения, контактирования: укр.: 1) вміння спілкуватися з людиною: слухати уважно, не перебивати, реагувати на запитання відповідями; 2) вид спілкування; вміння спілкуватись відповідно до ситуащї; рус.: 1) способ общения, при котором собеседники готовь усльшиать друг друга; 2) умение вести диалог с учетом особенностей коммуникативной ситуации; лит.: 1) dalijimasis informacija tarp dvieju ar daugiau individu;; 2) komunikacijos procesas; dialogas, polilogas, kai visi bendraujantieji stengiasi;

2) взаимодействие, сотрудничество, партнерство, честная игра: укр.: 1) співпраця, яка спрямована на пошук вирішення питань, завдань; 2) взаємодія, співробітництво; спільне, однакове уявлення комунікативних норм, ролей у взаєминах; рус.: 1) взаимодействие, партнерство, готовность к сотрудничеству; 2) готовность воспринимать то, что говорит другой человек, заинтересованно и непредвзято; 3) сотрудничество на принципах честной игрьг; лит.: 1) tai yra squeika tarp dvieju ar daugiau žmonių; 2) kooperatyvumas man reiškia nusiteikima bendradarbiauti; 
3) коллективизм (объединение, группа, сообщество, команда): укр.: 1) робота в групах, колективність; згуртованість та об, єднаність; 2) спільна праця, вміння працювати в команді; рус.: 1) умение работать в коллективе; 2) чувство солидарности на ментальном уровне; 3) готовность действовать сообща; 4) способность и предпочтение действовать в команде; лит.: 1) kalbëjimasis, bendrai leidžiamas laisvalaikis, bendras darbas; 2) gebejimas dirbti komandoje;

4) компромиссность, общность цели и намерений, учет интересов Другого: укр.: 1) пошук компромісів, уникнення конфліктів; 2) прагнення досягти спільного знаменника; 3) здатність враховувати інтереси співрозмовника; рус.: 1) желание найти общее решение, возможно, путем компромиссов; 2) желание вникнуть в ситуацию, понять и учесть в процессе совместной деятельности или разговора потребности, интересь и желания другого человека, умение подстроиться ради достижения совместных целей, старание былть открытылм к иньлм точкам зрения, возможность пренебречь частью свочх интересов ради помощи другому; 3) согласованность намерений; лит.: 1) komunikacijos aktas, kuriame svarbu informacijos siuntëjas, gavejas, perdavimo kanalas, jvairaus pobūdžio triukšmas (aplinka), dalyviu tikslai ir pasirengimas bei noras bendrauti (kalbèti, aktyviai klausyti, siekti bendro sutarimo ir pan.); 2) bendraujame siekdami bendrų tikslų;

5) норма этикета, вежливость, воспитанность, толерантность, искренность: укр.: 1) точність, правильність, ивидкість, логічність мовлення; 2) вихованість у спілкуванні; 3) здатність швидко порозумітись не вдаючись в детальні пояснення / роз'яснення, особливо під час вирішення різних проблемних ситуацій; рус.: 1) взаимоотношения, основаннье априори на взаимном уважении, открьгтости, искренности и готовности помочь; 2) правильность и логичность вьссказьвваний; 3) такт, непредвзятость, ориентированность на партнера по коммуникации, уважение к его мнению и нуждам; лит.: 1) atviras, tolerantiškas bendravimas; 2) keitimasis informacija, žmogišku santykių plètojimas ir palaikymas; 
6) другие: укр.: 1) форма організацї економічної діяльності людей $i$ організацій для спільного досягнення загальних цілей або задоволення потреб. Використовується також для позначення характеру економічних та політичних взаємин; 2) не знаю; 3) рішення проблеми; 4) народження нової ідеї тощо; 5) використання таких мовних засобів, які 6 сприяли встановленню дружніх відносин із співрозмовником; рус.: 1) преимущественная манера поведения; 2) выбранная манера поведения; 3) общая экономическая и предпринимательская деятельность людей; лит. 1) apsikeičiama mintimis, emocijomis, susipažistama; 2) keitimasis informaciniais ženklais; 3) žmoniu apsikeitimas paslaugomis; 4) abiem pusèms malonus ir naudingas laiko leidimas kartu.

Позволим себе прокомментировать отдельные моменты, касающиеся последнего типа стереотипных представлений о когнитивнокоммуникативной категории кооперативности. Так, информанты из трёх исследуемых лингвокультур, не имеющие высшего образования, представляющие средний социальный статус и не являющиеся филологами и педагогами, чаще всего давали короткий ответ “не знаю”. Общей для украинских, русских и литовских респондентов была апелляция к “кооперации советского образца”, поскольку в те времена «кооперативными» называли магазины. Именно поэтому довольно распространенными, особенно среди украинцев и русских, были ответы, связанные с экономической и предпринимательской деятельностью, реже - политической и общественной. Среди литовских реципиентов значительное количество реакций касались любых типов и реализаций “обмена” (мыслями, эмоциями, чувствами, знаками, материальными вещами и т.д.). Общей для информантов трех рассматриваемых коммуникативных культур была зависимость содержания ответов от профессионально-деятельностной принадлежности реципиентов. Так, педагоги часто связывали понятие “кооперативность” c “определенным (кооперативным) методом обучения в группе”, а специалисты-психологи с “кооперативной деятельностью”. Общую характеристику количественно-качественных показателей мы предлагаем в таблице № 1 . 
Таблица № 1

\section{Стереотипные представления украинцев, русских и литовцев о кооперативном поведении на фоне когнитивно-коммуникативной категории кооперативности}

\begin{tabular}{|c|c|c|c|c|c|c|c|}
\hline \multirow[b]{2}{*}{$\begin{array}{l}\text { Коммуни- } \\
\text { кативная } \\
\text { культура }\end{array}$} & \multirow[b]{2}{*}{$\begin{array}{l}\text { Общее } \\
\text { количество } \\
\text { выделенных } \\
\text { реакций рес- } \\
\text { пондентов }\end{array}$} & \multicolumn{6}{|c|}{$\begin{array}{c}\text { Количественно-качественная характеристика } \\
\text { стереотипных представлений о понятии } \\
\text { когнитивно-коммуникативной категории } \\
\text { кооперативности }\end{array}$} \\
\hline & & 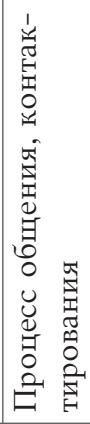 & 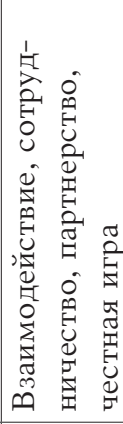 & 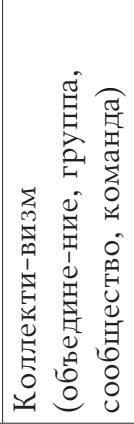 & 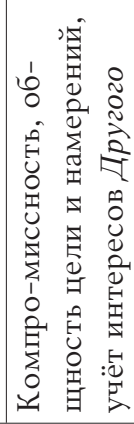 & 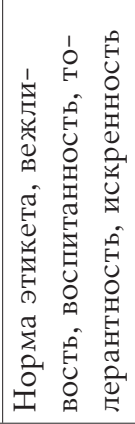 & 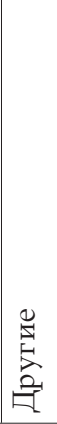 \\
\hline Украинская & $110(100 \%)$ & 22 & 22 & 18 & 28 & 8 & 12 \\
\hline Русская & $126(100 \%)$ & 20 & 26 & 27 & 32 & 12 & 9 \\
\hline Литовская & $113(100 \%)$ & 34 & 36 & 7 & 12 & 9 & 15 \\
\hline
\end{tabular}

При классификации ответов респондентов из трёх исследуемых коммуникативных культур было идентифицировано пять типов стереотипных представлений о понятии “кооперативная языковая личность” (для облегчения восприятия мы предлагали информантам вопрос “Какого человека Вы можете назвать “кооперативным” в общении?"):

1) конструктивная, компромиссная, неконфликтная, толерантная, вежливая: укр.: 1) толерантна людина; 2) конструктивна людина, яка надає перевагу неконфліктному спілкуванню, спрямованому на взаємовигідну співпрацю; 3) людина, яка робить певний внесок у спілкування, якого вимагає загальноприйнятий конструктивний характер розмови; 4) здатна слухати, готова відиукувати рішення, вдаючись до необхідних компромісів; рус.: 1) человек, ищущий во время общения устраивающее всех участников решение; 2) человек, идущий навстречу в процес- 
се коммуникации, способньлй вести конструктивньлй диалог; 3) гибкий, идущий на компромисс человек, готовьгй принять чужую точку зрения с целью договориться; 4) готовьий к сотрудничеству, к поиску компромиссов и общих решений коммуникант; лит.: 1) gebantis ne tik transliuoti savo idëjas ir požiūrï, bet ir priimti kita žmogu; 2) tolerantiškas asmuo, pasirengęs kompromisui; 3) nevengiantis santykio ir ryšio su kitais žmonèmis, jo ieškantis ir ji skatinantis; 4) teigiamai nusiteikęs, pasirengęs aktyviai dalyvauti diskusijoje, mokantis girdèti ir argumentuoti, gebantis keisti požiūri, jei ịtikino kita šalis;

2) коммуникабельная, активная, инициативная, приверженная к командной, партнёрской, коллективной деятельности: укр.: 1) комунікабельна людина, здатна не лише говорити, а й слухати; 2) людина, яка бере активну участь у спілкуванні й вирішенні різних питань (проблем), активно й ефективно працює в команді; 3) ініціативна у спілкуванні людина, частіше - екстраверт, майже завжди готова до контакту (взаємодії) з іншими; 4) особа, яка бажає встановити партнерські відношення зі співрозмовником; рус.: 1) коммуникабельньий человек, способньий общаться с любым собеседником; 2) человек, который готов к общению в коллективе, заинтересован в командном взаимодействии; 3) человек, легко идущий на контакт, проявляющий инициативу в общении; 4) активньий коммуникант, способньий работать в команде; лит.: 1) šnekus, komunikabilus, iniciatyvus, drąsus žmogus; 2) lengvai užmezgantis kontakta, tarpasmeninio bendravimo santykius; 3) asmuo, priklausantis $X$ socialinei bendrijai, linkęs užmegzti kontakta su kitu žmogumi; 4) komunikuojantis žmogus, mégstantis kalbèti su kitais, pradedantis naujas pokalbio temas, aktyviai dalyvaujantis pokalbiuose, lengvai susirandantis naujų pažinčių;

3) умная, прагматичная, с высоким уровнем языковой и коммуникативной компетенции: укр.: 1) дотримується норм, правил, комунікативних законів залежно від конкретної ситуацї, тематики спілкування; враховує психологічний стан співрозмовника заради безконфліктного та ефективного спілкування; 2) розумна людина з критичним мисленням, яка вміє добре аргумен- 
тувати власну позицію і переконання; 3) людина, яка швидко, логічно може здійснювати комунікацію, володіє мовними і мовленнєвими засобами спілкування на високому рівні; 4) здатна правильно побудувати діалог (організовувати процес спілкування), лаконічно висловлюватись $з$ метою досягнення спільної комунікативної мети; рус.: 1) человек, умеющий слушать, понимать и обобцать; 2) коммуникант, соблюдающий язьковьле и речевье нормьл, умело достигающий поставленньх целей; 3) умеющий общаться, излагать доступно свою точку зрения для успешного и правильного решения какой-либо задачи (обьчно в профессиональной сфере); 4) человек, способньий найти общий язык с собеседниками и добиться общего коммуникативного поведения, используя нормативньле языковьле формыл; лит.: 1) pagal situacija tinkamai pokalbiu ir kūno kalba su kitu komunikuojantis žmogus šiam tikslui pasiekti; 2) bendraujantis žmogus - tai visu bendra tiksla ir kiekvieno situacijos dalyvio vaidmeni suvokiantis žmogus, išnaudojantis kalbinę situacija bendram (ne savo!) tikslui pasiekti; 3) tas, kuris moka užmegzti ir palaikyti kontaktą; kuris girdi ir geba suprasti, kas jam sakoma; 4) santykius su kitais palaikantis ir normatyvine kalba vartojantis žmogus;

4) искренняя, справедливая, открытая, эмоциональная, чувствительная, внимательная: укр.: 1) людина-екстраверт, не егоїстична; 2) людина, яка навчена манерам солідарності, рівності, справедливості; 3) людина, яка відчуває свого співбесідника; 4) людина, яка намагається поводити себе якомога привітніше $i$ готова співчувати; рос.: 1) открьтыльй, внимательньий и вникающий в предмет обсуждения, прислушивающийся к собеседнику коммуникант; 2) человек, готовьий воспринимать чужое мнение, даже если заведомо не согласен с ним, умеющий относиться к иной точке зрения и мировоззрению с уважением; 3) внимательньий, тактичньй, чувствительньий человек; 4) излучающий позитивную энергию собеседник, которьий делится положительньми эмоциями; лит.: 1) пиоširdus užsikrètęs žmogus; 2) asmuо, sutelkęs dèmesị i pašnekova, kuriam yra skiriama jo žinute; 3) žmogus, atvirai besidalijantis savo mintimis ir jausmais su kitais žmonèmis 
ir besidomintis kitu žmoniu mintimis ir jausmais; 4) atviras asmuo, linkęs dalytis savo mintimis ir emocijomis;

5) другие: укр.: 1) людина, яка визнає своє незнання чогось або неправоту та водночас вимагає цього від співрозмовника; 2) комунікант, що може і хоче чути та почути та водночас не боїться висловити власну думку та відстоює іï; 3) успішна завзята людина, здатна до самостійних дій; 4) однодумець; 5) поступлива особистість; рос.: 1) для общения отдельного человека с окружающими вместо этого термина (“кооперативный” - И. К.) используется “коммуникабельный”; 2) человек с гибкой коммуникационной матрицей; 3) смелая и находчивая в общении личность, имеющая твердый характер; 4) не знаю; лит.: 1) drasus, pozityvus žmogus; 2) norintis ir gebantis užmegzti ryšị su bet kurios lyties, tautybès ir padetties asmeniu, susitarti; 3) girdintis kita žmogus bei nebijantis pats reikšti savo minčiu; 4) aš nežinau.

Прокомментируем последний тип стереотипных представлений украинцев, русских и литовцев о понятии “кооперативная языковая личность”. Так, информанты из трёх исследуемых лингвокультур, не имеющие высшего образования, представляющие средний социальный статус и не являющиеся филологами и педагогами, чаще всего давали короткий ответ “не знаю”. Общей для украинских, русских и литовских респондентов была апелляция к таким чертам характера кооперативной языковой личности, как укр.: сміливість (рішучість), завзятість (рус.: твёрдость, сила воли; лит.: drasa, valia).

Мы можем предположить, что, по мнению опрошенных, именно такой, как правило, прагматично ориентированный коммуникант способен удачно реализовывать кооперативные коммуникативные стратегии посредством соответствующих тактик и достигать желаемого перлокутивного эффекта, поставленной цели, решая конкретные задачи в процессе общения. Универсальными, но не очень распространенными, являются такие определения кооперативной языковой личности, как укр.: однодумець; поступлива людина; друг; рус.: единомьишленник; уступчивый человек; друг; лит.: vienmintis, nuolankus žmogus, draugas. Соответственно остались индивидуальными следующие стереотипные представления о понятии “кооперативная языковая личность”: укр.: вимоглива; успішна; рус.: находчивая личность; лит.: gebantis susitarti su 
bet kurios lyties, tautybès ir padèties asmeniu. Относительно приведенного русскими респондентами замечания о взаимозаменяемости понятия “кооперативная / коммуникабельная языковая личность”, не можем с ними согласиться, поскольку глубоко убеждены в том, что кооперативный коммуникант способен не только быстро устанавливать и поддерживать контакт, а, в первую очередь, успешно реализовывать во время этого контакта фатическую функцию, достигая обоими (или более) собеседниками цели коммуникации и желаемого перлокутивного эффекта. Общую характеристику количественно-качественных показателей стереотипных представлений украинцев, русских и литовцев о понятии “кооперативная языковая личность” предлагаем в таблице № 2 .

Таблица № 2

\section{Стереотипные представления украинцев, русских и литовцев} о понятии “кооперативная языковая личность”

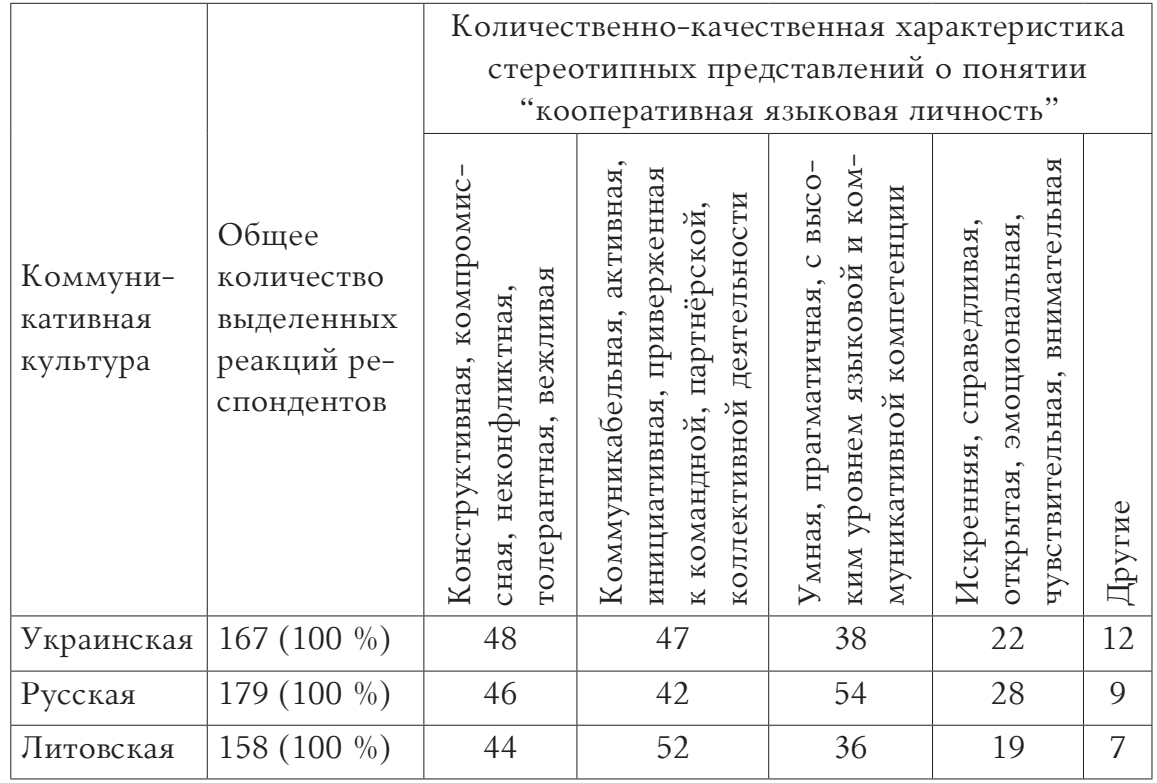

В следующем блоке анкеты респондентам была предоставлена возможность выбрать из предложенного перечня стереотипные ситуации общения, в которых чаще всего реализуется когнитивно-ком- 
муникативная категория кооперативности (то есть - стереотипные кооперативные коммуникативные ситуации). Информанты могли одновременно выбрать несколько типов стереотипных кооперативных коммуникативных ситуаций, как и добавить новый (тип), если, по их мнению, таковой отсутствовал. Таким образом, результаты по трём исследуемым лингвокультурам мы подаем в таблице № 3.

Таблица № 3

\section{Стереотипные ситуации общения, в которых чаще всего реализуется когнитивно-коммуникативная категория кооперативности}

\begin{tabular}{|c|c|c|c|c|}
\hline $\begin{array}{c}\text { Тип кооперативной } \\
\text { коммуникативной ситуации }\end{array}$ & Украинцы & Русские & Литовцы & $\begin{array}{c}\text { Средний } \\
\text { показатель }\end{array}$ \\
\hline $\begin{array}{l}\text { Привітання, приветствие, } \\
\text { pasisveikinimas }\end{array}$ & $47,1 \%$ & $45,5 \%$ & $80,6 \%$ & $57,7 \%$ \\
\hline $\begin{array}{l}\text { Знайомство, знакомство, } \\
\text { pažintis }\end{array}$ & $65,9 \%$ & $51,5 \%$ & $88,9 \%$ & $68,8 \%$ \\
\hline $\begin{array}{l}\text { Порада, совет, } \\
\text { patarimas }\end{array}$ & $57,6 \%$ & $63,6 \%$ & $86,1 \%$ & $69,1 \%$ \\
\hline $\begin{array}{l}\text { Побажання, пожелание, } \\
\text { palinkejjimas }\end{array}$ & $38,8 \%$ & $42,4 \%$ & $80,6 \%$ & $53,9 \%$ \\
\hline $\begin{array}{l}\text { Подяка / вдячність, благо- } \\
\text { дарность / признательность, } \\
\text { dėkingumas }\end{array}$ & $54,1 \%$ & $48,5 \%$ & $61,1 \%$ & $54,6 \%$ \\
\hline $\begin{array}{l}\text { Прохання, просьба, } \\
\text { prašymas }\end{array}$ & $49,4 \%$ & $66,7 \%$ & $83,3 \%$ & $66,5 \%$ \\
\hline $\begin{array}{l}\text { Похвала, похвала, } \\
\text { pagyrimas }\end{array}$ & $44,7 \%$ & $36,4 \%$ & $77,8 \%$ & $53 \%$ \\
\hline $\begin{array}{l}\text { Запрошення, приглашение, } \\
\text { pakvietimas }\end{array}$ & $54,1 \%$ & $39,4 \%$ & $86,1 \%$ & $59,9 \%$ \\
\hline $\begin{array}{l}\text { Вибачення, извинение, } \\
\text { atsiprašymas }\end{array}$ & $55,3 \%$ & $60,6 \%$ & $86,1 \%$ & $67,3 \%$ \\
\hline $\begin{array}{l}\text { Виправдання, оправдание, } \\
\text { pasiteisinimas }\end{array}$ & $25,9 \%$ & $45,5 \%$ & $72,2 \%$ & $47,9 \%$ \\
\hline $\begin{array}{l}\text { Прощання, прощание, } \\
\text { atsisveikinimas }\end{array}$ & $29,4 \%$ & $36,4 \%$ & $80,6 \%$ & $48,8 \%$ \\
\hline $\begin{array}{l}\text { Згода, согласие, } \\
\text { sutarimas }\end{array}$ & $67,1 \%$ & $72,7 \%$ & $80,6 \%$ & $73,5 \%$ \\
\hline
\end{tabular}




\begin{tabular}{|l|l|l|l|l|}
\hline \multicolumn{1}{|c|}{$\begin{array}{c}\text { Тип кооперативной } \\
\text { коммуникативной ситуации }\end{array}$} & Украинцы & Русские & Литовцы & $\begin{array}{c}\text { Средний } \\
\text { показатель }\end{array}$ \\
\hline $\begin{array}{l}\text { Співчуття, сочувствие, } \\
\text { užuојаuta }\end{array}$ & $49,4 \%$ & $48,5 \%$ & $69,4 \%$ & $55,8 \%$ \\
\hline $\begin{array}{l}\text { Освідчення в коханні, при- } \\
\text { знание в любви, } \\
\text { meilès рrisipažinimas }\end{array}$ & $38,8 \%$ & $30,3 \%$ & $72,2 \%$ & $47,1 \%$ \\
\hline $\begin{array}{l}\text { Iнші, другие, } \\
\text { kitas }\end{array}$ & $7,1 \%$ & $15,2 \%$ & $2,8 \%$ & $8,4 \%$ \\
\hline
\end{tabular}

Критическим средним показателем для дальнейшего анализа национального кооперативного коммуникативного поведения считаем 50 \%. Именно поэтому такие коммуникативные ситуации, как “оправдание”, “прощание” и “признание в любви” не будут рассматриваться в качестве кооперативных. Что касается конкретных показателей по исследуемым коммуникативным культурам, должны отметить, что, по мнению литовцев, все предложенные ситуации общения являются кооперативными, поскольку результаты анкетирования значительно превышают критический показатель 50 \%. Степень кооперативности отдельных коммуникативных ситуаций (“приветствие”, “пожелание”, “похвала”, “приглашение”, “оправдание”, “прощание”) почти в два раза выше в литовской лингвокультуре, чем в украинской и русской. Более детальный анализ указанных в таблице показателей мы представим в следующих предметных публикациях, сделав, соответственно, предварительные выводы относительно стереотипных представлений украинцев, русских и литовцев об уровне их кооперативности. На данный момент приведенные цифры служат нам для репрезентации стереотипных представлений представителей трёх исследуемых коммуникативных культур о кооперативном коммуникативном поведении и помогут разрешить следующую поставленную задачу в представленной работе.

Касающимся проблематики статьи, связанной с параметризацией уровней авто- и гетеростереотипов о кооперативной языковой личности в украинской, русской и литовской лингвокультурах, является понятие этнокультурного стереотипа, детально разработанное M. А. Шутовой в аспекте когнитивно-ономасиологической рекон- 
струкции фразеоформул с целью конструирования стереотипных этнокультурных портретов англичан и украинцев. По ее мнению, которое она отстаивает, ссылаясь на А. А. Уфимцеву (Уфимцева 1995), этнокультурные стереотипы являются симбиозом этнических и культурных, в котором первые (этнические) являются фактами этикетного поведения коллективного бессознательного (архетипов), которым невозможно специально “научиться” (онтологический характер), а вторые - фактами поведения как индивидуального бессознательного, так и сознательного, которым можно “научиться”. Этнокультурные стереотипы, по определению украинской исследовательницы, являются культурно-этносоциальным явлением, а этнокультурная стереотипизация - лингвокогнитивным процессом, связанным со способностью сознания человека к категоризации (классификации, таксономии) различных объектов, явлений и собственно самих представителей различных этнокультурных групп (Шутова 2016, 244-245).

В следующем блоке анкеты информантам было предложено с помощью методики ранжирования выявить уровень кооперативности коммуникативного поведения интерактантов, принадлежащих к родной и другим (анализируемым нами) лингвокультурам (см. результаты в таблице № 4). Таким образом, удалось установить авто- и гетеростереотипные индивидуальные и коллективные представления об уровне кооперативности украинцев, русских и литовцев. Реципиенты могли выбрать один из шести вариантов ответов: очень кооперативное (поведение), кооперативное, преимущественно кооперативное, преимущественно некооперативное, некооперативное и другое.

Первые три параметра можно трактовать как положительное проявление признака, и, соответственно, по содержанию аффективного компонента как положительный стереотип, четвертый и пятый - отрицательный, а шестой характеризует и отражает, как правило, индивидуальные стереотипные представления с дополнительной индивидуально-личностной окраской. Для корректного описания и анализа тенденций в вопросе выявления уровня кооперативности коммуникативного поведения украинцев, русских и литовцев цифры мы перевели в проценты (жирным шрифтом в таблице обозначены автостереотипы). По нашему мнению, отношение суммы первых трех вариантов ответов (иногда к ним необходимо добавить реакции респондентов из 
шестого варианта с положительным семантическим компонентом), превышающее 50 \%, должно свидетельствовать о положительном коллективном авто- и гетеростереотипном представлении. Соответственно, если сумма четвертого и пятого вариантов с учётом реакций информантов с шестого варианта, эксплицирующих выраженную негативную оценку, превышает 50 \%, то и авто-, гетеростереотипные представления маркируются как негативные.

Таблица № 4

Авто- и гетеростереотипные представления украинцев, русских и литовцев о6 уровне кооперативности их коммуникативного поведения

\begin{tabular}{|c|c|c|c|c|}
\hline \multirow{2}{*}{\multicolumn{2}{|c|}{$\begin{array}{c}\text { Уровень кооператив- } \\
\text { ности коммуника- } \\
\text { тивного поведения } \\
\text { украинцев, русских и } \\
\text { литовцев }\end{array}$}} & \multicolumn{3}{|c|}{ Коммуникативная культура респондентов } \\
\hline & & \multirow{2}{*}{$\begin{array}{l}\text { Украинская } \\
\\
4 \% \\
\end{array}$} & Русская & Литовская \\
\hline \multirow{3}{*}{$\begin{array}{l}\text { Очень коо- } \\
\text { перативное } \\
\text { (поведение) }\end{array}$} & Укр. & & $8 \%$ & $12 \%$ \\
\hline & Pyc. & $2 \%$ & $3 \%$ & $23 \%$ \\
\hline & Лит. & $10 \%$ & $6 \%$ & $3 \%$ \\
\hline \multirow{3}{*}{$\begin{array}{l}\text { Кооператив- } \\
\text { ное }\end{array}$} & Укр. & $30 \%$ & $20 \%$ & $38 \%$ \\
\hline & Pyc. & $14 \%$ & $12 \%$ & $40 \%$ \\
\hline & Лит. & $36 \%$ & $11 \%$ & $21 \%$ \\
\hline \multirow{3}{*}{$\begin{array}{l}\text { Преимущест- } \\
\text { венно коопе- } \\
\text { ративное } \\
\end{array}$} & Укр. & $42 \%$ & $18 \%$ & $22 \%$ \\
\hline & Pyc. & $33 \%$ & $44 \%$ & $21 \%$ \\
\hline & Лит. & $37 \%$ & $55 \%$ & $46 \%$ \\
\hline \multirow{3}{*}{$\begin{array}{l}\text { Преимущест- } \\
\text { венно некоо- } \\
\text { перативное }\end{array}$} & Укр. & $11 \%$ & $40 \%$ & $18 \%$ \\
\hline & Pyc. & $31 \%$ & $29 \%$ & $4 \%$ \\
\hline & Лит. & $6 \%$ & $12 \%$ & $24 \%$ \\
\hline \multirow{3}{*}{$\begin{array}{l}\text { Некоопера- } \\
\text { тивное }\end{array}$} & Укр. & $6 \%$ & $7 \%$ & $5 \%$ \\
\hline & Pyc. & $17 \%$ & $3 \%$ & $7 \%$ \\
\hline & Лит. & $3 \%$ & $11 \%$ & $3 \%$ \\
\hline \multirow[t]{3}{*}{ Другое } & Укр. & $7 \%$ & $7 \%$ & $5 \%$ \\
\hline & Pyc. & $3 \%$ & $9 \%$ & $5 \%$ \\
\hline & Лит. & $8 \%$ & $5 \%$ & $3 \%$ \\
\hline
\end{tabular}

Относительно автостереотипных представлений, то в трёх исследуемых коммуникативных культурах, суммарные показатели свидетельствуют о положительной оценке уровня кооперативности соб- 
ственного коммуникативного поведения. Так, 76 \% украинцев, 59 \% русских и 70 \% литовцев считают своё коммуникативное поведение кооперативным. Необходимо отметить, что русские, отвечающие в категории “Другое”, чаще давали положительную характеристику своему коммуникативному поведению. Таким образом, мы можем констатировать, что в трёх представленных лингвокультурах автостереотипные представления в целом подтверждают кооперативный характер коммуникативного поведения.

Гетеростереотипные представления украинцев об уровне кооперативности литовцев в общении демонстрируют позитивный характер $83 \%$, что значительно превышает показатель автостереотипных и свидетельствует о высокой положительной оценке. Гетеростереотипные представления украинцев об уровне кооперативности русских достигают 49 \%, но необходимо отметить, что в категории “Другое” два ответа позитивно маркированы по этому вопросу, поэтому общий показатель находится на грани отрицательной и положительной оценки. Соответствующую, почти тождественную картину наблюдаем и в гетеростереотипных представлениях русских, 46 \% которых (и еще три ответа из категории “Другое”) определяют коммуникативное поведение украинцев как кооперативное. Относительно гетеростереотипных представлений русских об уровне кооперативности в общении литовцев, то 72 \% оценивают его положительно. Литовцы, в свою очередь, высоко позитивно оценивают уровень кооперативности коммуникативного поведения украинцев и русских, 72 \% и 84 \% соответственно.

Полученные результаты можем прокомментировать, ссылаясь на суждения респондентов, отраженные в анкете в их ответах. Очевидно, что на стереотипные представления информантов об уровне кооперативности коммуникативного поведения, кроме их собственного опыта контакта и общения, влияет множество различных моментов. В частности речь идет об экстралингвистических факторах, связанных с современными геополитическими, региональными вопросами, а также с пока еще продолжающимися процессами самоидентификации языково-культурной идентичности этносов, которые в свое время жили в одном государстве и по сей день имеют достаточно активные и распространенные связи между собой, обусловленные прежде 
всего географическими, историческими, политическими, а отчасти генетическими и национальными причинами.

Таким образом, можем сделать предварительные выводы о том, что кооперативность свойственна представителям украинской, русской и литовской коммуникативных культур, способным найти оптимальные и эффективные пути для успешного взаимодействия и конструктивного сотрудничества, которые достигаются в процессе общения открытого, а порой даже откровенного характера с высокой степенью искренности и заинтересованности в решении вопросов, важных для всех участников коммуникации.

Можем выделить универсальные для украинской, русской и литовской лингвокультур стереотипные представления о понятии когнитивно-коммуникативной категории кооперативности: 1) взаимодействие и сотрудничество с партнером по коммуникации; 2) умение, способность и намерение работать в команде; 3) приверженность принципу взаимодействия, его чёткое соблюдение; 4) способность извлекать пользу из взаимодействия, сотрудничества; 5) соблюдение принципа “честной игры” по общим установленным правилам; 6) заинтересованность не только в личной выгоде, но и понимание, учёт интересов партнера; достижение как индивидуальных, так и общих целей коммуникации.

Последствия и преимущества удачной реализации когнитивнокоммуникативной категории кооперативности в процессе общения состоят в том, что интерактантам удается сохранять устойчивые позиции по отношению к собеседникам (партнерам, конкурентам и т.п.), направляя прагматично ориентированные усилия в русле сотрудничества. Кооперативность помогает устанавливать равновесие в социальных отношениях, способствует конструктивности в решении конфликтов различного характера (бытовых, семейных, партнёрских, коллективных, профессиональных, межнациональных, этнических, политических, даже религиозных и военных и т.д.).

Литература

Dabartinès lietuvių kalbos žodynas 2006 (internetinė versija 2011) - Dabartinés lietuvių kalbos žodynas. Redaktorių kolegija: Stasys Keinys (vyr. redaktorius), Laimutis Bilkis, 
Jonas Paulauskas, Vytautas Vitkauskas. Vilnius: Lietuvių kalbos institutas. Prieiga internetu: http://dz.lki.lt/word/kooperacija/ [žiūrèta 201605 15].

Castano \& other 2002 - Castano E., Paladino M.-P., Coull A. Protecting the ingroup stereotype: Ingroup identification and the management of deviant ingroup members. The British journal of social psychology. Vol. 41 (3), p. 365-386.

Kučinskaitė 1990 - Kučinskaitè A. Lietuviu kalbos etiketas. 2-asis pataisytas ir papildytas leidimas. Vilnius: Mokslas, 110 p.

Löschmann 2001 - Löschmann M. Was tun gegen Stereotype? Interkulturelle Kommunikation in Wirtschaft und Fremdsprachenunterricht. Gerhard Wazel. Institut für Interkulturelle Kommunikatione. V. (Hrsg.). Frankfurt-am-Main: Lang, S. 147-201.

Quasthoff 1989 - Quasthoff U. M. Ethnozentrische Verarbeitung von Informationen: Zur Ambivalenz der Funktionen von Stereotypen in der interkulturellen Kommunikation. Wie verstehen wir Fremdes? Aspekte zur Klärung von Verstehensprozessen. München, S. $37-62$.

Большая психологическая энциклопедия 2007 - Большая психологическая энциклопедия. Под ред. Н. Дубенюк. Москва: Эксмо. Prieiga internetu: http://www.psyoffice. ru/5-psychology-988.htm [žiūrèta 201605 10].

Бухаева 2015 - Бухаева Р. В. Этнокультурные стереотипь речевого общения (на материале бурятского языка). Дис. ... докт. филол. наук: 10.02.19 «Теория языка». Улан-Удэ, с. 104.

Донец 2001 - Донец П. Н. К типологии стереотипов. Социальная власть языка. Воронеж: Изд-во ВГУ, с. 183-188.

Карасик 1992 - Карасик В. И. Язык социального статуса. Москва: Ин-т языкознания РАН; Волгогр. гос. пед. ин-т, 330 с.

Коммуникативное поведение 2007 - Коммуникативное поведение. Под ред. И. А. Стернина. Вып. 27. Русское, литовское, эстонское и латышское коммуникативное поведение. Воронеж: Изд-во «Истоки», 237 с.

Корольов 2016 - Корольов І. Р. Методологія і методика дослідження національної кооперативної комунікативної поведінки. Studia Linguistica. Київ: Видавничий дім Дмитра Бураго. Вип. 9.

Ларина 2009 - Ларина Т. В. Категория вежливости и стиль коммуникации. Сопоставление английских и русских лингвокультурных традиций. Москва: Рукописные памятники Древней Руси, 507 с.

Леонтович 2005 - Леонтович О. А. Русские и американцы: парадоксы межкультурного общения. Москва: Гнозис, 352 с.

Лихачёва 2007 - Лихачёва А. О6 особенностях литовской коммуникативной культуры в связи с понятием «национальный характер». Коммуникативное поведение. Вып. 27. Русское, литовское, эстонское и латьциское коммуникативное поведение. Воронеж: Изд-во «Истоки», с. 4-16.

Метёлкина 2002 - Метёлкина Ю. С. Социальные стереотипь: процессы формирования, видь и использование в политике (информационньий подход). Автореф. дис. ... канд. социол. наук. Новосибирск, 18 с.

Нельсон 2003 - Нельсон Т. Психология предубеждений. Секреты шаблонов мьшления, восприятия и поведения. СПб.: Прайм-Еврознак, 384 с. 
Ожегов 2006 - Ожегов С. И., Шведова Н. Ю. Толковьй словарь русского языка. Москва: ИТИ Технологии, 944 с. Prieiga internetu: http://www.ozhegov.com/words/13130. shtml [žiūrèta 201605 10].

Паужа 2007 - Паужа Й. Особенности русского и литовского коммуникативного поведения в ситуациях проявления речевого этикета. Коммуникативное поведение. Вып. 27. Русское, литовское, эстонское и латышское коммуникативное поведение. Воронеж : Изд-во «Истоки», С. 16-31.

Семендяева 1986 - Семендяева О. Ю. Стереотип как социальный и социально-психологический феномен. Дис. ... канд. филос. наук: 09.00.09 «Прикладная социология». Москва, 195 с.

Скаб 2015 - Скаб М. Спільне і відмінне у комунікаційній поведінці українців та поляків. Studia Ucrainica Varsoviensia. № 3. Warszawa, c. 5-6. Prieiga internetu: http:// www.ukraina.uw.edu.pl/sites/default/files/pliki/SUV\%203\%20-\%20pi\%C4\%85te.pdf (žiūrèta 201605 10).

Словник української мови 1973 - Словник української мови: в 11-ти томах. Ред. колег. І. К. Білодід (голова) та ін. Київ: Наукова думка. Т. 4, с. 277. Prieiga internetu: http://sum.in.ua/s/kooperacija [žiūrèta 201605 10].

Солдатова 1998 - Солдатова Г. У. Психология межэтнической напряженности. Москва: Смысл, 389 с.

Сорокина 2013 - Сорокина Н. В. Методическая типология стереотипов как компонент содержания обучения иностранным языкам в вузе. Язык и культура $=$ Langue et Culture. № 3 (23), c. 120-139.

Стернин 2015 - Стернин И. А. Модели описания коммуникативного поведения. Воронеж: «Гарант», 52 с.

Стефаненко 1999 - Стефаненко Т. Г. Этнопсихология. Москва: Институт психологии РАН, Академ. проект, 320 с.

Уфимцева 1995 - Уфимцева Н. В. Этнические и культурные стереотипы: кросс-культурное исследование. РАН ИАН. Сер. Литература и язык. Т. 54, № 3, с. 52-73.

Уфимцева 1996 - Уфимцева Н. В. Русские: опыт еще одного самопознания. Этнокультурная специфика языкового сознания. Москва: Институт языкознания РАН, c. $139-162$.

Федотова 2016 - Федотова С. В. Восприятие социального статуса личности в современном российском обществе. Автореф. дис. ... канд. психол. наук: 19.00 .05 «Социальная психология». Москва, 34 с.

Шутова 2016 - Шутова М. О. Етнокультурні стереотипні портрети англійців $i$ українців (когнітивно-ономасіологічна реконструкція фразеоформул). Київ: Видавничий центр КНЛУ, 293 с. 


\section{Igor Korolyov}

STEREOTYPICAL IMPRESSIONS OF UKRAINIANS, RUSSIANS AND LITHUANIANS ABOUT COOPERATIVE COMMUNICATIVE BEHAVIOR (due to the results of empirical research)

Summary

The article has been written within the framework of modern trends in linguistics - linguistics communicative studies, socio- and psycholinguistics, linguistics cultural studies. The topic of the article deals with the topical issue - the study of stereotypical impressions of East Slavic (Ukrainian and Russian) and Baltic (Lithuanians) ethnic groups of cooperative communicative behavior. Due to the fact that the anthropocentrism, expansionism and explanatory are the dominant principles, the necessity to analyze the subject of research in modern linguistics deals with the accumulation of considerable material relating to communication problems of various types (conflict, intermediate, cooperative), mono- and intercultural communication, communicative behavior of a language person. The process and mechanisms of stereotyping the national communicative behaviour have been characterized, the individual and collective stereotypical impressions about the concept of "cooperativity", as well as the cooperative linguistic individual in Ukrainian, Russian and Lithuanian communicative cultures have been identified on the results of empirical research (due to the socio- and psycholinguistic experiments). The universal and national specific parameters of auto- and hetero-stereotypes of Ukrainian, Russians and Lithuanians on their level of cooperativity in communication have been established.

The preliminary correct conclusions are the results of careful and meticulous research (identification, description, characteristics, systemization and parametrization) of individual and collective auto- and hetero-stereotypical impressions of Ukrainians, Lithuanians and Russian about cooperative communicative behaviour. The cooperativity belongs to the representatives of Ukrainian, Russian and Lithuanian communicative cultures able to find the best and effective way for successful interaction and constructive cooperation, which is achieved in the process of open communi- 
cation, and sometimes even explicit nature with a high degree of sincerity and interest in issues important for all participants of communication.

We can highlight the universal for the Ukrainian, Russian and Lithuanian linguocultures stereotypical impressions about the concept of cognitive and communicative categories of cooperativity. They are: 1) the interaction and cooperation with partner in communication; 2) the ability, capacity and willingness to work in a team; 3) the commitment to cooperation principle, its strict observance; 4) the ability to benefit from the interaction, cooperation; 5) the compliance with the principle of "fair play" in the general rules; 6) the interest not only in personal gain, but also the understanding, the account of partner's interests; the achievement of both individual and general communication purposes.

The effects and advantages of the successful implementation of the cognitive and communicative categories of cooperativity in the communication process consist in the following: the interaktants manage to maintain a stable position with respect to the interlocutors (partners, competitors, etc.), directing pragmatically oriented efforts towards cooperation. The cooperativity helps to establish a balance in social relations; it promotes to achieve the constructiveness in solving the conflicts of different nature (household, family, partnership, collective, professional, international, ethnic, political, religious and even military, etc.). 